F. Reprod. Fert. (1970) 23, 103-108

\title{
COMPARATIVE EFFECTS OF METHYLENE, ETHYLENE AND PROPYLENE DIMETHANESULPHONATES ON THE MALE RAT REPRODUCTIVE SYSTEM
}

\author{
E. R. A. COOPER AND H. JAGKSON \\ Unit of Reproductive Pharmacology, University of Manchester, and \\ Experimental Chemotherapy, Paterson Laboratories, \\ Christie Hospital and Holt. Radium Institute, Manchester
}

(Received 1st December 1969)

\begin{abstract}
Summary. Histological changes in the rat testis were correlated with the antifertility effects of injections of three diol diesters of methanesulphonic acid. The compounds are consecutive members of a homologous series each differing by $-\mathrm{CH}_{2}-$ from its neighbours. The diester of ethylene glycol (EDS) caused antispermatogenic effects resembling those following hypophysectomy and was associated with involution of prostate and epididymis; spermatocoele formation occurred in the latter organ. Methylene dimethanesulphonate and 1,3-propylene dimethanesulphonate induced changes consistent with spermatogonial damage resembling those produced by Myleran (busulphan).
\end{abstract}

\section{INTRODUCTION}

Simple diesters of methanesulphonic acid produce characteristic antifertility effects in rodents (Jackson, 1964, 1966) and show chemosterilant activity in insects (Crystal, 1968; LaChance, Degrugillier \& Leverich, 1969). In the latter species, the effects involve sterilization of spermatozoa (induction of 'dominant lethal mutations') with surprisingly little effect on the proliferative stages of the spermatogenic process. This contrasts with the actions of the diesters in rodents, particularly the rat, where damage to pre-meiotic cells characteristically leads to sterility associated with aspermia due to interruption of the spermatogenic process.

Inhibition of spermatogonial development after the diester busulphan (Myleran, $\mathrm{n}=4$, Text-fig. 1) was inferred from earlier studies (Jackson, Fox<smiles>CCC(C)OC(=O)O[Sb](C)(C)C</smiles>

Text-rig. 1. General formula for diol-diesters of methanesulphonic acid.

\& Craig, 1961) but has recently been ascribed to a lethal action on these cells (de Rooij \& Kramer, 1968). The present work compares the histological and antifertility effects of three lower members of the same homologous series of diesters, propylene dimethanesulphonate (PDS, $n=3$ ), ethylene dimethanesulphonate (EDS, $\mathrm{n}=2$ ) and methylene dimethanesulphonate (MDS, $\mathrm{n}=1$ ). 


\section{METHODS}

Male rats of proven fertility, approximately $350 \mathrm{~g}$ in weight, were used with adequate controls. Standard diet and water were freely available, all animals being housed in identical conditions. Single doses of the three compounds were injected intraperitoneally (i.p.) dissolved or suspended in arachis oil and groups of three animals were killed at appropriate intervals up to 45 days after the dose.

The testes with epididymides in situ were liberated by severing the vas a little beyond its origin at the cauda. From the severed end, a sample of seminal fluid (cauda fluid) was examined in normal saline for sperm content and motility and the entire organ was fixed in Bouin's fluid. Transverse or longitudinal sections were made at the upper pole of the testis including the caput, at the equator including the corpus and at the lower pole including the cauda epididymidis. The histological effects of the compounds were assessed qualitatively by reference to testis tubules at stages V, VIII and XIII of spermatogenesis, according to the classification of Perey, Clermont \& Leblond (1961).

\section{EXPLANATION OF PLATES}

V, VIII, XIII: testis tubules at stages V, VIII, XIII according to Perey et al. (1961); A, B: spermatogonium type-A and type-B; SC: spermatocyte; ST: spermatid; SZ: spermatozoa; S: cell of Sertoli; SL: spermatocoele; G: giant cell (cluster of spermatids); $\mathbf{M}$ : cell in mitosis; $\mathbf{R}$ : tubule recovering.

\section{PLATE 1}

Fig. 1. MDS, 6 days after injection $(15 \mathrm{mg} / \mathrm{kg})$. Fewer spermatocytes but spermatids and spermatozoa appear normal. $\times 455$.

Fig. 2. MDS, 12 days after injection. Reduction of spermatocytes allowed spermatids to lie on the basement membrane. $\times 490$.

FIG. 3. MDS, 45 days after injection. Repopulation conspicuous in the majority of tubules. $\times 150$.

Fig. 4. EDS, 12 days after injection $(75 \mathrm{mg} / \mathrm{kg})$. Tubule stages unidentifiable. $\times 455$.

\section{PLATE 2}

Fig. 5. EDS, 13 days after injection $(75 \mathrm{mg} / \mathrm{kg})$. Spermatocoele (SL) present in the cauda epididymidis. $\times 14$.

FIG. 6. EDS, 12 days after injection. Mitotic figures presumably of spermatogonial origin. $\times 490$.

FIG. 7. EDS, 20 days after injection. Several type-A spermatogonia and numerous resting spermatocytes are consistent with active repopulation; a giant cell is present. $\times 455$.

FIG. 8. EDS, 28 days after injection. This section illustrates the patchiness of the repopulation process. $\times 150$.

PLATE 3

Fig. 9. EDS, 28 days after injection $(75 \mathrm{mg} / \mathrm{kg})$. Some tubules appear to have escaped serious damage. $\times 455$.

Fic. 10. PDS, 12 days after injection $(50 \mathrm{mg} / \mathrm{kg})$. Depletion of spermatocytes; spermatids are present on the basement membrane. $\times 455$.

FIG. 11. PDS, 20 days after injection. Marked depopulation with giant cell formation. Some remaining spermatozoa cling to Sertoli cells. $\times 490$.

Fig. 12. PDS, 28 days after injection. As for Fig. 11. $\times 150$.

\section{PLATE 4}

Fig. 13. PDS, 33 days after injection $(50 \mathrm{mg} / \mathrm{kg})$. Mitotic figures in cells on the basement membrane indicate re-initiation of spermatogenesis. $\mathbf{M}_{1}$ is in telophase, $\mathbf{M}_{2}$ is in anaphase. $\times 525$.

Fig. 14. PDS, 45 days after injection. Type-A and $B$ spermatogonia are present in some tubules; type-B cells form a conspicuous ring on the basement membrane. $\times 150$.

Fig. 15. PDS $(1 \times 100 \mathrm{mg} / \mathrm{kg}), 52$ days after injection. No spermatogenesis. Intertubular stroma increased. $\times 245$. 

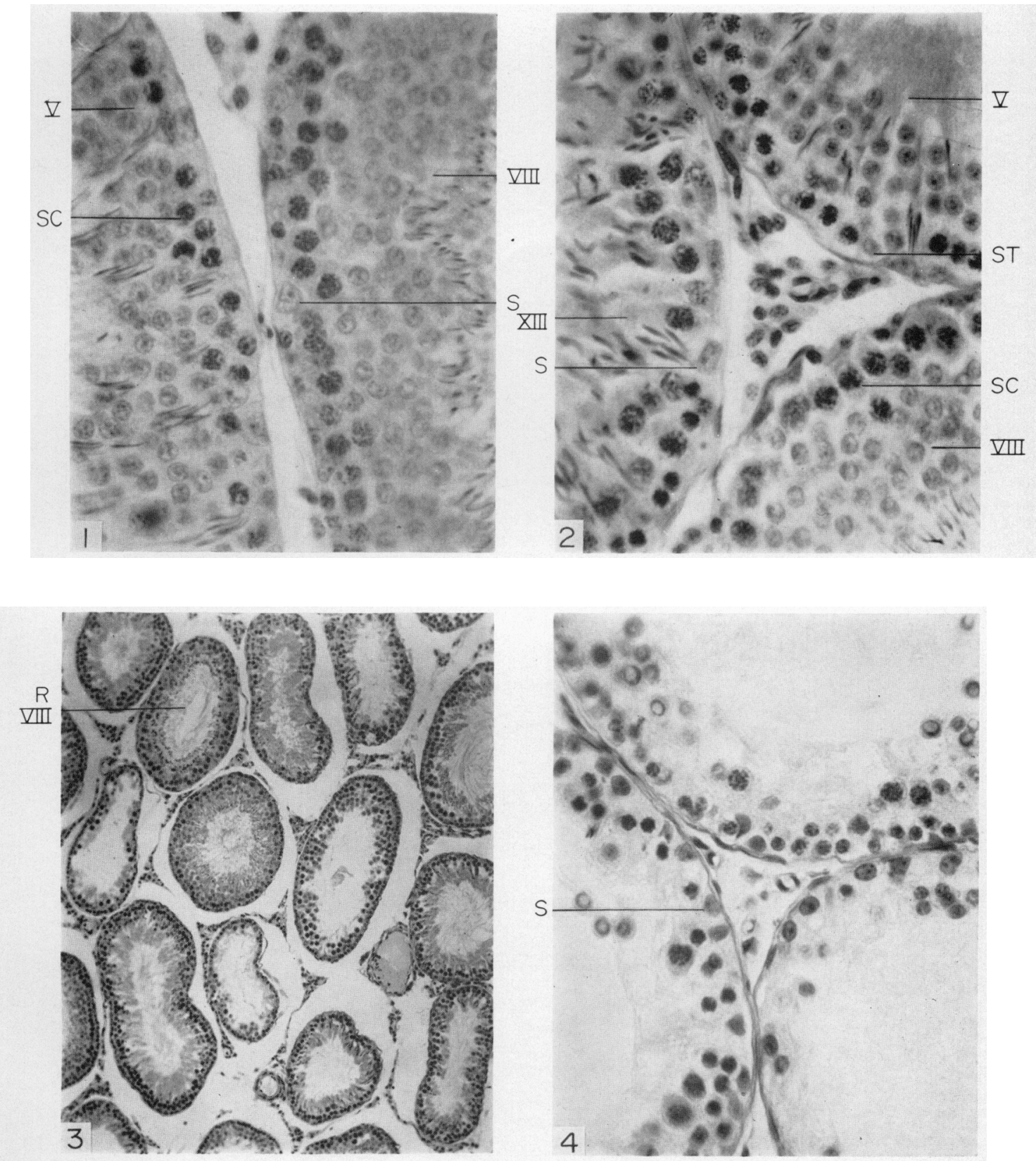

(liacing f. 104) 
PLATE 2
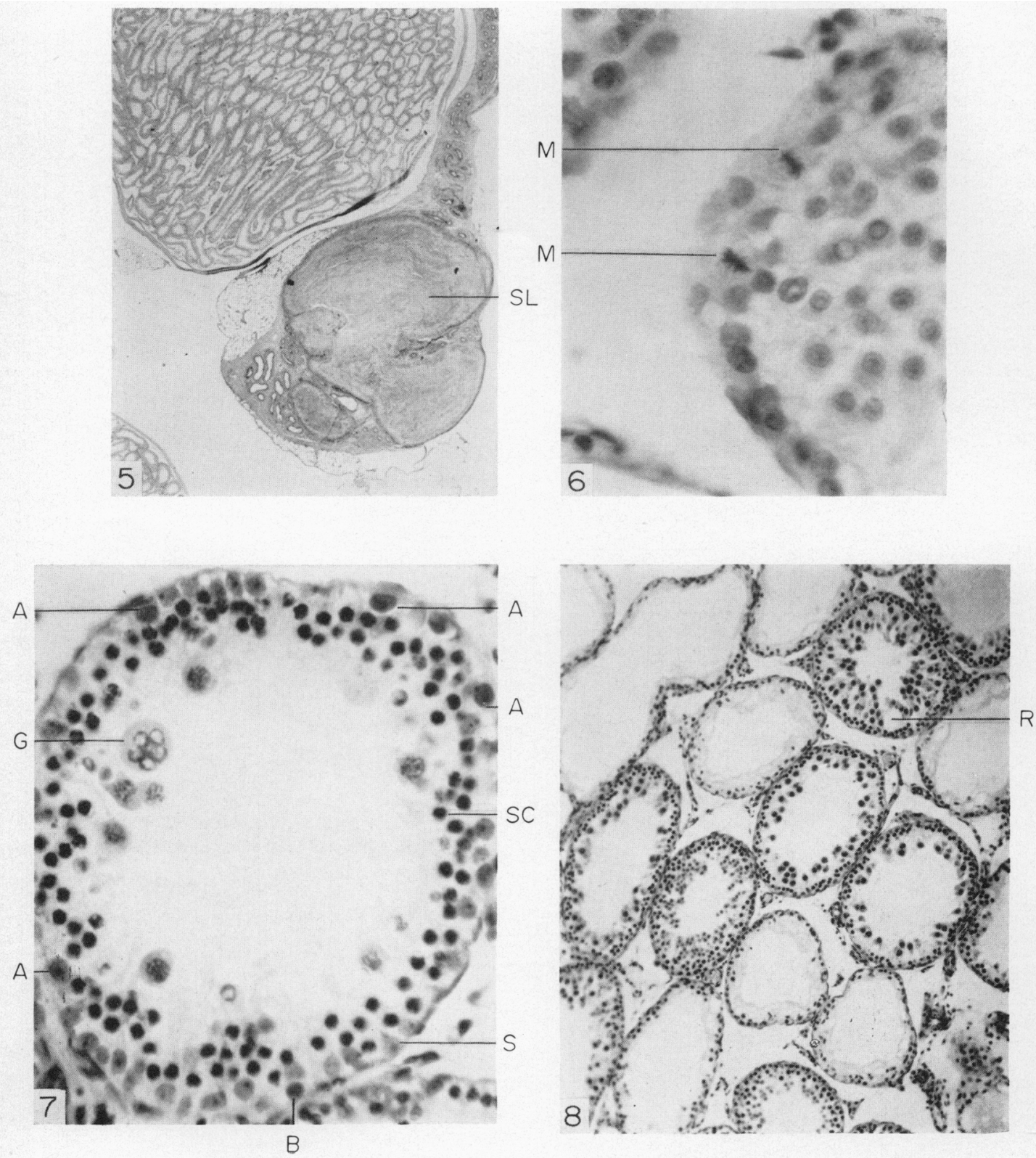


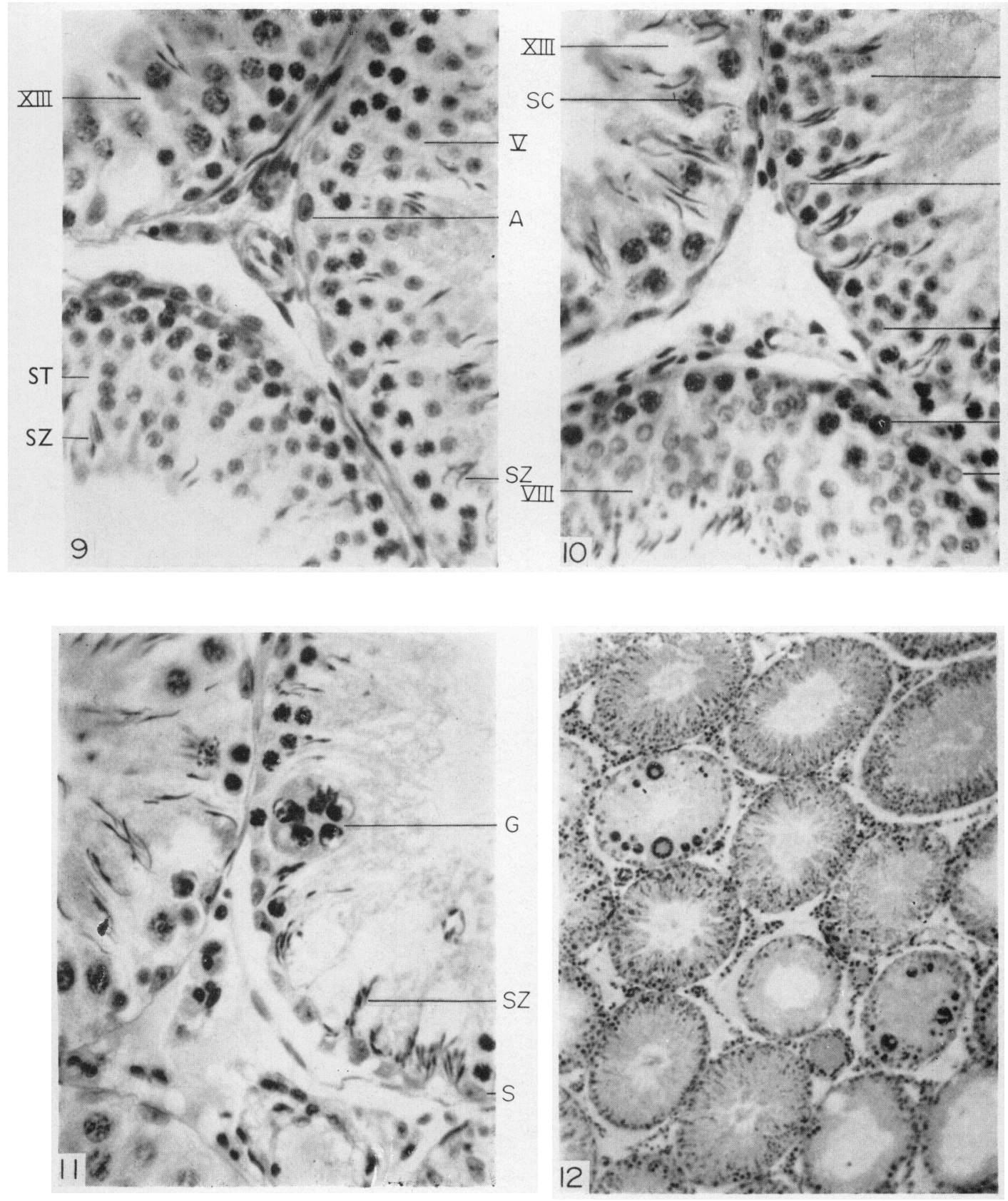



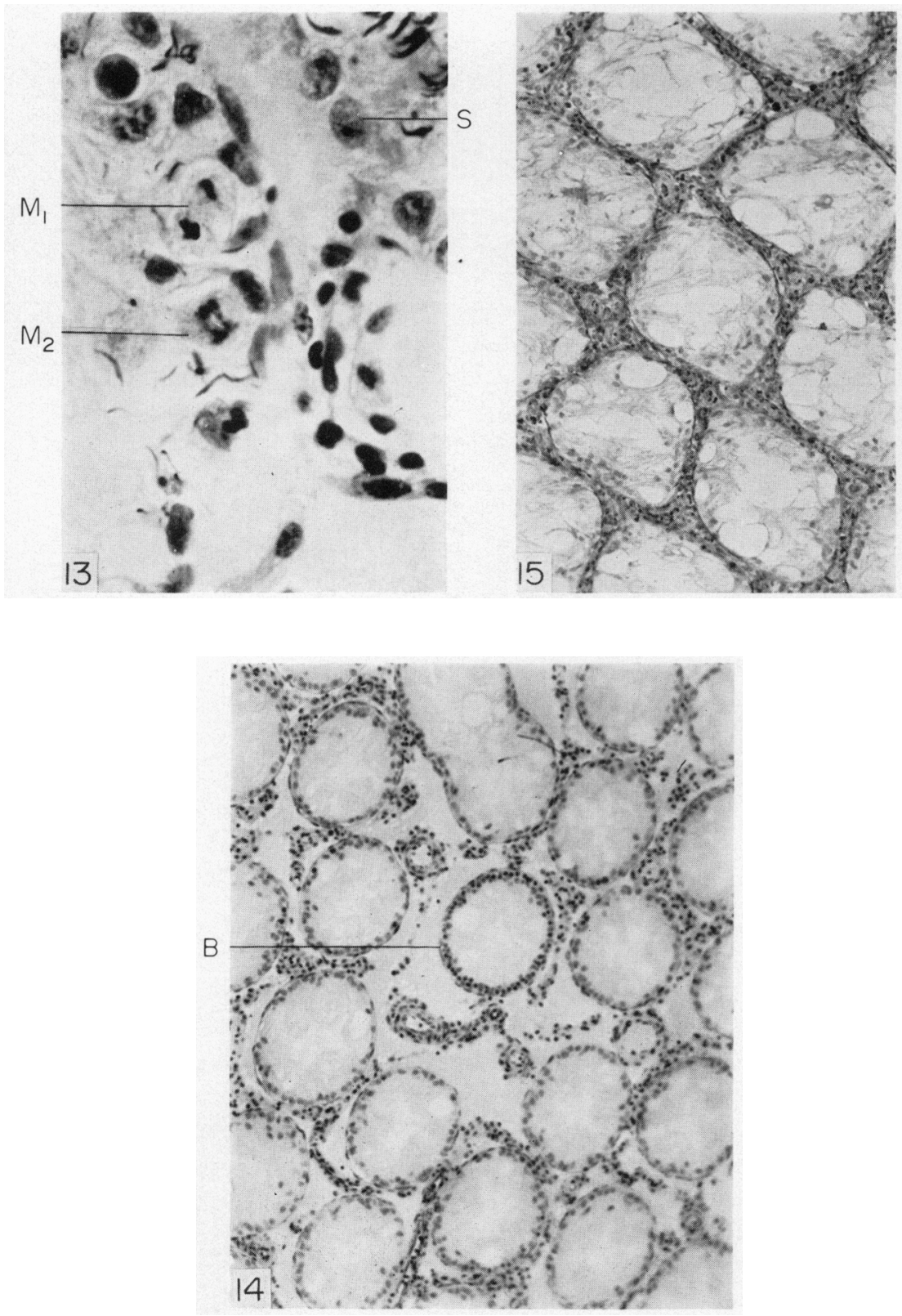


\section{RESULTS}

Methylene dimethanesulphonate, $15 \mathrm{mg} / \mathrm{kg}$

At autopsy, 3, 6 and 9 days after the injection, the testes were of normal size, weight and appearance. The cauda fluid contained motile spermatozoa and histologically the epididymis was normal. In the testes, a change was apparent at Day 3, spermatogonia being less numerous in some tubules. By Day 6, resting spermatocytes and pachytene spermatocytes were fewer in the scattered tubules but spermatids and spermatozoa appeared normal, the latter maintaining contact with the Sertoli cells (Pl. 1, Fig. 1). Later still (Day 12), spermatocytes became even less frequent so that here and there spermatids lay on the basement membrane but the characteristic arrangement of both spermatids and spermatozoa was not affected (Pl. 1, Fig. 2).

Many tubules did not show any arrest of spermatogenesis by Day 24. In a minority of tubules, however, only the Sertoli cells remained, although by Day 28 , spermatogonia and resting spermatocytes had re-appeared in some tubules and type-A spermatogonia were more frequent. Repopulation of some damaged tubules was apparent at Day 33 and conspicuous by Day 45, although a few lagged behind (Pl. 1, Fig. 3).

The continued presence of motile spermatozoa in the cauda fluid indicated that interference with spermatogenesis by MDS at this dose level was incomplete. Leydig cell function seemed unaffected since the prostate and seminal vesicles remained normal throughout.

\section{Ethylene dimethanesulphonate, $75 \mathrm{mg} / \mathrm{kg}$}

EDS produced a striking loss in weight of the testes in this series, and the prostate and seminal vesicles became progressively smaller, reaching an average minimum value for the prostate of only $0.27 \mathrm{~g}$ at Day 28 . This increased to $0.44 \mathrm{~g}$ at Day 33 and $0.51 \mathrm{~g}$ at Day 45 , compared to $0.74 \mathrm{~g}$ for the controls.

In these animals, a striking feature was the presence of spermatocoeles in the epididymis. Macroscopically, these resembled pustules and were encountered in all parts of this organ (Pl. 2, Fig. 5). In some areas of the epididymis, cells appeared degenerate and at other sites, the epithelium was hyperplastic. Sometimes, proximal to the spermatocoele, the epididymal canal was distended by contents while distally it was empty. This effect may depend upon whether or not the lesion caused a complete block to the transport of spermatozoa.

In the testes, following EDS treatment, no noticeable change was observed until Day 6, when the characteristic pattern of spermatozoa in stage VIII tubules had disappeared and spermatids were depleted. By Day 9, spermatocytes were also reduced in number but type-A spermatogonia were more frequent. On Day 12, the tubule stages could not be identified (Pl. 1, Fig. 4) although pre-meiotic cells were seen alongside the Sertoli cells and rather compressed against the basement membrane. The mitotic figures seen among such cells (Pl. 2, Fig. 6) are presumably spermatogonial and account for the repopulation evident by Day 20 (Pl. 2, Fig. 7), resulting in complete spermatogenesis in the majority of tubules by 45 days. Surviving pre-meiotic cells must be responsible for a proportion of tubules showing advanced spermatogenesis 
about Day 28 (Pl. 2, Fig. 8, and Pl. 3, Fig. 9). Giant cells formed from clumps of spermatids were occasionally seen (Pl. 2, Fig. 7).

\section{Propylene dimethanesulphonate, $50 \mathrm{mg} / \mathrm{kg}$}

The average weight of the testis after 1 week in the series injected with PDS was $2.2 \mathrm{~g}$ (control $2 \cdot 1 \mathrm{~g}$ ) and on Day 45 , only $0.82 \mathrm{~g}$; that of the prostate was $0.69 \mathrm{~g}$ compared to the control value of $0.78 \mathrm{~g}$.

By Day 3, type-B spermatogonia and resting spermatocytes in the testis tubules were reduced in number so that pachytene spermatocytes were already found upon the basement membrane, whilst spermatozoa retained their normal relation to the Sertoli cells. By Day 12, all types of spermatocytes were depleted and spermatids were seen on the basement membrane (Pl. 3, Fig. 10). In some tubules, spermatids were clumped into giant cell formations but Sertoli cells and their attached spermatozoa still remained (Day 20; PI. 3, Fig. 11).

Disappearance of spermatogenic cells continued although giant cells persisted (PI. 3, Fig. 12), until by Day 33, the tubules were mainly populated by a ring of Sertoli cells. However, an occasional nucleus in mitosis was now observed (Pl. 4, Fig. 13), indicating the re-initiation of spermatogenesis. On Day 45 , type-A and $B$ spermatogonia had reappeared in the scattered depleted tubules, the latter type forming a conspicuous ring on the basement membrane (Pl. 4, Fig. 14).

In this series of sections, the epididymis contained spermatozoa until Day 20 but subsequently the tube became empty and collapsed. Interstitial cells seemed to be more conspicuous from Day 20.

Five rats were given $1 \times 100 \mathrm{mg} / \mathrm{kg}$ i.p. In one survivor, no spermatogenic cells were present in the tubules 7 weeks later but only the scattered nuclei of Sertoli cells and some cytoplasmic remnants. The intertubular stroma was increased and contained PAS-positive cells (Pl. 4, Fig. 15).

\section{DISCUSSION}

Studies of the effects of these sulphonic esters on male rat fertility have shown that each exerts characteristic actions on the spermatogenic process. MDS produced only an initial phase of sterility consistent with damage to epididymal spermatozoa, although a short course of treatment $(5 \times 5 \mathrm{mg} / \mathrm{kg})$ revealed a second period of infertility commencing in Week 8, arising from spermatogonial inhibition (Fox \& Jackson, 1965). The present histological study has shown that the single dose is followed by an obvious reduction in the number of type-B spermatogonia within a few days and subsequent loss of spermatocytes, though the degree of interference was insufficient to cause sterility. Maturation depletion only occurred in a minority of tubules. The remarkable 'functional' impairment of spermatozoa by this compound would, of course, have no impact on testis histology.

PDS clearly had a more general destructive action on pre-meiotic cells, their disappearance from the tubular epithelium being conspicuous by Day 12 post-treatment. This was further indicated by the considerable reduction of both spermatids and spermatozoa by Day 20, whilst giant cell formation from clumps of spermatids occurred frequently. 
Four weeks after PDS, many of the tubules contained only Sertoli cells and, as after busulphan, occasional mitotic figures among cells on the basement membrane indicating re-initiation of spermatogenesis were not seen until 33 days after the injection. Even so, the majority of tubules was still depleted at 45 days, the sequence of events contrasting with the progressive and smooth disappearance of spermatogenic cells beyond the spermatogonial block imposed by busulphan, the next highest homologue (Jackson et al., 1961).

Surprisingly, the antifertility pattern of both these homologues was similar; evidently, sufficient normal spermatozoa continue to be produced after PDS to maintain normal fertility for about 8 weeks, in spite of the destructive effects revealed by histology. However, sterility then lasted for at least 10 weeks after this dose of PDS. A similar histological sequence followed the administration of isopropyl methanesulphonate (Jackson et al., 1961), the sequential disappearance of cells being apparently speeded up (Partington, Fox \& Jackson, 1964). In this instance, however, sterility developed 5 weeks after the dose of $100 \mathrm{mg} / \mathrm{kg}$ i.p. (Jackson et al., 1961). The action of busulphan was much more selective against type-A spermatogonia and the rate of disappearance of other cells present at the time of treatment was consistent with the established timing of spermatogenic events in the rat (Partington et al., 1964).

After EDS, sterility developed in Week 2, fertility returning a few weeks later with a dose of $50 \mathrm{mg} / \mathrm{kg}$ but only after more than 10 weeks at a dose of $100 \mathrm{mg} / \mathrm{kg}$. The histological changes differed considerably from those seen after MDS, PDS or busulphan. Rapid disappearance of seminiferous cells occurred retrospectively, spermatozoa and spermatids being first affected. By Day 12, only a proportion of early spermatocytes and spermatogonia remained among the Sertoli cells at the periphery of the tubules, the stages of which were no longer recognizable. The entire testis was affected, although peripheral cells in the tubules were viable and mitotic figures were present; by Day 20, many type-A and B spermatogonia were identified but their distribution was patchy. The presence of spermatids and spermatozoa in some tubules by Day 28 implies that some pre-meiotic cells remained unaffected and were able to continue development. At the conclusion of the series, the majority of the tubules were fully spermatogenic, consistent with restoration of fertility.

Whilst the action of EDS appears to be explained by direct interference with spermatogenic cells, its destructive effects towards spermatids and spermatocytes and the observed temporary involution of prostate and seminal vesicles in the rat suggest endocrine-mediated damage, perhaps by way of impaired Leydig cell function.

The other remarkable feature of the action of this compound, which may be relevant to this hypothesis, is the formation of spermatocoeles in the rat epididymis. These lesions will be discussed in a subsequent communication but it is interesting that the other diesters studied did not produce such changes in the rat, or regressive changes in the accessory organs. In the mouse, much larger doses of EDS were required to produce temporary sterility, whilst a near-lethal single dose $(500 \mathrm{mg} / \mathrm{kg}$ i.p.) neither caused changes in testis histology nor induction of spermatocoeles. This is a curious circumstance since the metabolic fate of EDS is similar in both species, the compound persists in the body and 
over $50 \%$ of the administered dose is recovered unchanged in the urine (Jackson \& Craig, 1969; Edwards, Craig, Jackson \& Jones, 1969).

\section{ACKNOWLEDGMENT}

This work was carried out with the support of grants from the Ford Foundation and Wellcome Trust.

\section{REFERENCES}

Crystal, M. (1968) Sulphonic acid esters as chemosterilants of screw-worm flies with particular reference to methanediol dimethanesulphonate. F. econ. Ent. 61, 2, 446.

DE Roorj, D. G. \& Kramer, M. F. (1968) Spermatogonial stem cell renewal in the rat, mouse and golden hamster. A study with the alkylating agent Myleran. Z. Zellforsch. mikrosk. Anat. 92, 400.

Edwards, K., Graig, A. W., Jackson, H. \& Jones, A. R. (1969) Studies with alkylating esters. I. The fate of ethylene dimethanesulphonate. Biochem. Pharmac. 18, 1693.

Fox, B. W. \& JACKson, H. (1965) In vivo effects of methylene dimethanesulphonate on proliferating cell systems. Br. F. Pharmac. Chemother. 24, 24.

JAGKson, H. (1964) The effects of alkylating agents on fertility. Br. med. Bull. $20,107$.

Jackson, H. (1966) Antifertility compounds in the male and female, p. 55. Thomas, Springfield, Illinois.

JACKSON, H. \& CRAIG, A. W. (1969) Effects of alkylating chemicals on reproductive cells. Ann. N.Y. Acad. Sci. 160, 215.

Jackson, H., Fox, B. W. \& Craig, A. W. (1961) Antifertility substances and their assessment in the male rodent. 7. Reprod. Fert. 2, 447.

LaGhance, L. E., Degrugillier, M. \& Leverich, A. P. (1969) Comparative effects of chemosterilants on spermatogenic stages in the housefly. I. Induction of dominant lethal mutations in mature sperm and gonial cell death. Mutat. Res. 7, 63.

Partington, M., Fox, B. W. \& Jackson, H. (1964) Comparative action of some methane sulphonic esters on the cell population of the testis. Expl Cell Res. 33, 78.

Perey, B., Glermont, Y. \& Leblond, G. P. (1961) The wave of the seminiferous epithelium in the rat. Am. F. Anat. 108, 47. 